\title{
Asymmetrical Interannual Variation in Aerosol Optical Depth over the Tropics in Terms of Aerosol-Cloud Interaction
}

\author{
Moeka Yamaji ${ }^{1}$, and Hiroshi G. Takahashi ${ }^{1,2}$ \\ ${ }^{1}$ Tokyo Metropolitan University, Hachioji, Japan \\ ${ }^{2} J a p a n$ Agency for Marine-Earth Science and Technology, Yokohama, Japan
}

\begin{abstract}
We statistically investigated an interannual co-variation among aerosol optical depth (AOD), cloud effective radius (CER), and precipitation, focusing on aerosol-cloud interaction over the tropics. A three-month composite analysis for AOD, CER, and precipitation for 2000-2012 based on El Niño-Southern Oscillation phases during September-October-November (SON) and December-January-February shows that an increase (decrease) in AOD in the El Niño (La Niña) years was associated with a decrease (increase) in precipitation, particularly in SON over the Maritime Continent. Additionally, CER decreased in the El Niño years over the same region, which implies that CER was associated with interannual variation in aerosol burden; these results were statistically significant. Interannual variation in AOD and CER in SON in the Maritime Continent was asymmetrical, which can be explained by stronger aerosol-cloud interactions under drier conditions. Specifically, large amounts of aerosols suppressed cloud and precipitation formation, which leads to decreases in wet deposition and increases in emission under warmer and drier surface conditions. This feedback results in asymmetrical variation. Furthermore, the asymmetrical interannual variation was confirmed statistically.
\end{abstract}

(Citation: Yamaji, M., and H. G. Takahashi, 2014: Asymmetrical interannual variation in aerosol optical depth over the tropics in terms of aerosol-cloud interaction. SOLA, 10, 185-189, doi: 10.2151/sola.2014-039.)

\section{Introduction}

Clouds play an important role in the global climate system because they can change the radiative budget and the hydrologic cycle. Cloud optical properties can be modulated by aerosols through the development of cloud particles and the formation of precipitation, which are aerosol indirect effects (Penner et al. 2001). These effects are one of the fundamental factors controlling global climate change. Knowledge of aerosol-cloud-precipitation interaction has been improved from IPCC-AR4 (Solomon et al. 2007), but is still low (Stocker et al. 2013).

Previous studies have investigated aerosol indirect effects using climate models and satellite data, and found that large amounts of aerosols can increase cloud droplets and suppress precipitation. Lohman and Lesins (2002) compared satellite-based data with simulation results to investigate the relative importance of the first and second indirect effects in their model. Suzuki et al. (2004) investigated the correlation between column aerosol particle number and cloud properties including effective radius, optical thickness, and liquid water path. Suzuki et al. (2006) conducted two experiments with a non-hydrostatic bin microphysics cloud model under different aerosol conditions (polluted and pristine) that showed a distinct difference in cloud particle growth. These features closely resemble the satellite-observed patterns reported by Nakajima and Nakajima (1995). Additionally, many previous observational studies have focused on biomass burning aerosols in the Amazon (Andreae et al. 2004) and Indonesia (Namajima et al.

Corresponding author: Hiroshi G. Takahashi, Tokyo Metropolitan University, Hachioji Tokyo 192-0397, Japan. E-mail: hiroshi3@tmu.ac.jp. (C2014, the Meteorological Society of Japan.
1999). These studies have shown that large amounts of aerosols suppress precipitation. Tosca et al. (2010) reported that black carbon absorption of solar radiation from fire-emitted aerosols caused anomalous warming in the troposphere, and that surface temperatures were reduced. Furthermore, they suggested that fire-emitted aerosols can suppress convection and precipitation because of increased atmospheric stability.

However most previous studies of aerosol indirect effects focused on a few extreme events in observational studies, such as a severe drought, or mean climatological conditions using numerical models. Ten years of satellite-observed aerosol optical depth (AOD) and cloud effective radius (CER) data are available. Stored satellite data may permit us to investigate aerosol-cloud-precipitation interaction climatologically, including interannual variations.

Generally, interannual variation is a fundamental climate variation, which is considerably larger than long-term climate changes. Recently, some previous studies suggested that interannual precipitation variation controls AOD on interannual time-scale by using these stored observational data (e.g., Jeoung et al. 2014; $\mathrm{Wu}$ et al. 2013). However, there are few studies also focusing on the aerosol-cloud-precipitation interactions although aerosol also affects cloud properties, such as CER and cloud number concentration, and precipitation development. Thus we focus on interannual variations in aerosol-cloud-precipitation interactions.

This study examines statistically significant co-variation among aerosols, cloud, and precipitation over the tropical and subtropical regions from long-term satellite observation in terms of interannual variations. We investigate whether the relationship among aerosols, cloud, and precipitation can be observed from only a few extreme events or many moderate events.

\section{Data and methodology}

\subsection{Datasets}

We used AOD and CER data from the Moderate Resolution Imaging Spectroradiometer (MODIS; Salomonson et al. 1989) remote sensors on board the two Earth-observing system satellites, Terra and Aqua, of the National Aeronautics and Space Administration. Both data from the Terra and Aqua satellites were used because of sampling problems in satellite data retrieval; these problems will be discussed in Section 2.3. The Level-3 MODIS Collection 051 Atmosphere Monthly Global Product was employed. We used AOD and CER data from the period March 2000/Terra and July 2002/Aqua through December 2012 on $1 \times 1$ degree cells.

In addition, this study used the monthly mean precipitation from the Global Precipitation Climatology Project (Adler et al. 2003 ) version 2.2 on $2.5 \times 2.5$ degree cells and monthly mean $850-\mathrm{hPa}$ zonal and meridional winds from the Japanese 25-year Re-Analysis Project (Onogi et al. 2007) on $2.5 \times 2.5$ degree cells for the period March 2000 through December 2012.

\subsection{Methodology}

To reveal whether the relationship among aerosols, cloud, and precipitation can be shown by only a few extreme events or many moderate events, global interannual co-variation among aerosols, cloud, and precipitation was investigated by composite analysis based on El Niño-Southern Oscillation (ENSO) phases because ENSO has one of the greatest impacts on regional and global climate on interannual time-scales. The analyzed area was 
$40^{\circ} \mathrm{N}-40^{\circ} \mathrm{S}$.

We used the extended reconstructed sea surface temperature (ERSST) v3b (Smith et al. 2008) anomalies over the Niño 3.4 region. We defined El Niño/La Niña years as years in which a three-month running anomaly of December-January-February (DJF) was greater/less than $+0.5 /-0.5 \mathrm{~K}$ for five consecutive overlapping seasons (Table 1).

We conducted composite analysis for the three-month mean for AOD, CER, precipitation, and 850-hPa winds during September-October-November (SON) and DJF. Anomalies from climatology in our study period were plotted when differences were statistically significant at a $95 \%$ confidence limit, as determined by Student's t-test.

\subsection{Uncertainties in satellite-observed datasets}

We examined AOD observation samples because AOD cannot be estimated below clouds. There are distinct diurnal cloud variations over the tropics, which means that clouds mainly exist over land in the early afternoon, and over the ocean in the morning. The equatorial crossing times of Terra and Aqua are approximately 10:30 and 13:30 (local solar time), respectively. Namely, Terra can frequently detect $\mathrm{AOD}$ over land and clouds over the ocean in the morning; whereas Aqua can mainly detect AOD over the ocean and clouds over land in the early afternoon. We reconfirmed that the number of AOD samples by the two satellites complemented each other.

Additionally, it was observed that AOD samples in DJF were less than those in SON, particularly in the La Niña years, which was probably caused by frequent heavy rainfall. Thus, the uncertainty of AOD in DJF for the La Niña years may be greater. $\mathrm{Wu}$ et al. (2013) have suggested that the monthly mean anomalies on a large gridbox average may have eliminated most of the systematic biases and reduced the uncertainties related to small spatial and temporal scale features. Referring to Shi et al. (2011), $\mathrm{Wu}$ et al. conducted sensitivity test to examine what extent cloud contamination may affect aerosol anomalies and the interannual aerosol-cloud relationship. They concluded that cloud contamination and cloud artifacts do not significantly alter AOD anomalies on an interannual time-scale.

\section{Results}

\subsection{Precipitation}

Here we investigate precipitation changes associated with ENSO, which can control AOD. Figure 1 shows well-known precipitation and wind anomalies associated with ENSO. In SON, statistically significant positive anomalies in precipitation over the tropical central Pacific Ocean and Indian Ocean, and negative anomalies in precipitation over the Maritime Continent, were observed in the El Niño years (Fig. 1a). On the other hand, precipitation and wind anomalies were essentially opposite in the $\mathrm{La}$ Niña years (Fig. 1b).

In DJF, statistically significant positive anomalies in precipitation over the tropical central Pacific Ocean and negative anomalies in precipitation over the Maritime Continent and Amazon region were observed in the El Niño years (Fig. 1c). On the other hand, precipitation and wind anomalies were essentially opposite in the La Niña years (Fig. 1d). Concurrent with these precipitation anomalies, we discuss the statistically significant co-variation in AOD and CER in the following subsections.

Table 1. Extracted El Niño/La Niña years based on ONI (http://www.cpc. ncep.noaa.gov/products/analysis_monitoring/ensostuff/ensoyears.shtml), which is a three-month running anomaly of ERSST v3b SST anomalies in the Niño 3.4 region $\left(5^{\circ} \mathrm{N}-5^{\circ} \mathrm{S}, 120^{\circ} \mathrm{W}-170^{\circ} \mathrm{W}\right)$.

\section{$\mathrm{SOND} / \mathrm{JF}$}

El Niño 2002/2003 2004/2005 2006/2007 2009/2010

La Niña 2000/2001 2005/2006 2008/2009 2010/2011 2011/2012
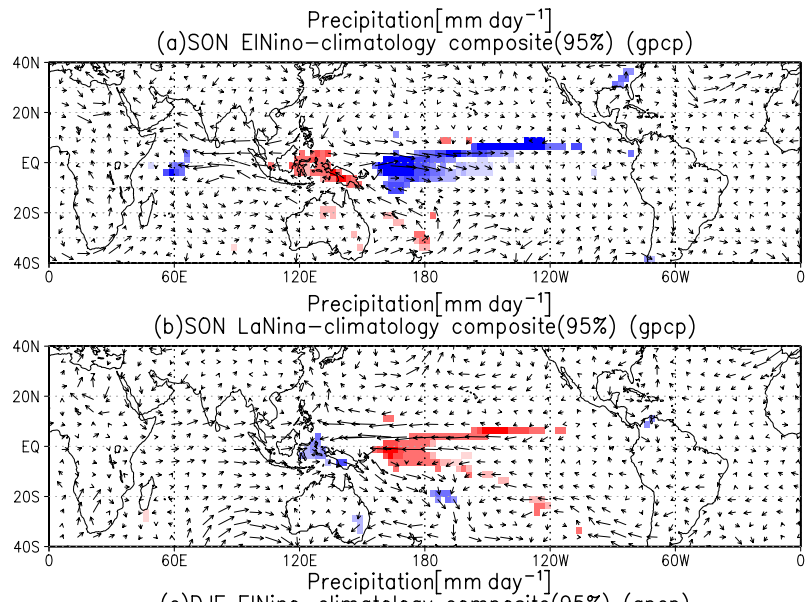

(c)DJF EINino-climatology composite(95\%) (gpcp)

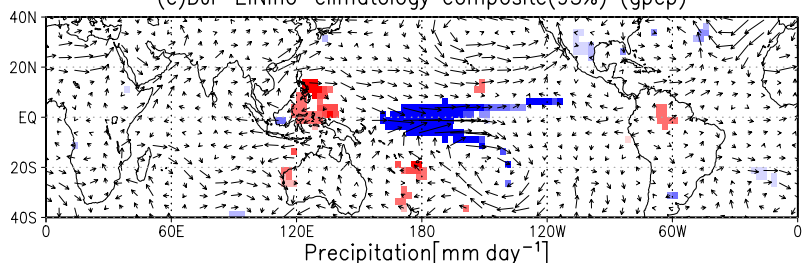

(d)DJF LaNina-climatology composite(95\%) (gpcp)

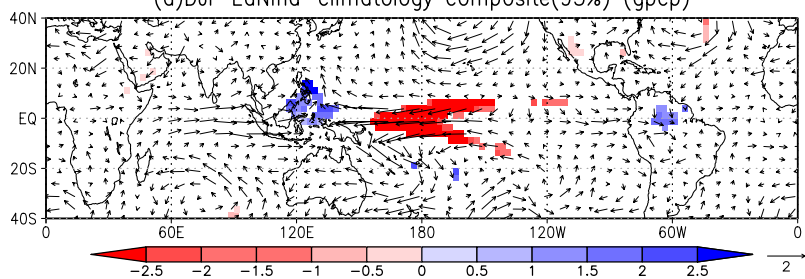

Fig. 1. Composite anomalies in monthly precipitation in (a) SON of the El Niño years, (b) SON of the La Niña years, (c) DJF of the El Niño years, and (d) DJF of the La Niña years $(95 \%$ confidence limit as determined by Student's t-test). The unit is $\mathrm{mm}^{\text {day }}{ }^{-1}$. Vectors indicate composite anomalies in monthly zonal and meridional winds. The wind scale is shown under the panels (unit is $\mathrm{m} \mathrm{s}^{-1}$ ).

\subsection{Aerosol Optical Depth \\ a. Interannual variation and its asymmetric property}

In SON, a statistically significant increase in AOD over the Maritime Continent and a decrease in AOD over the tropical central Pacific Ocean, western Indian Ocean, off the coast of California, and the southern Atlantic Ocean were observed in the El Niño years (Fig. 2a). In the La Niña years, an increase in AOD over the tropical central Pacific Ocean and southern Atlantic Ocean, and a decrease in AOD over the Maritime Continent were observed (Fig. 2b). These signals were essentially opposite over the Maritime Continent, tropical central Pacific Ocean, and southern Atlantic Ocean between the El Niño and La Niña years.

In DJF, positive signals in AOD over Australia and the tropical eastern Pacific Ocean, and negative signals in AOD over the eastern and western Indian Ocean and tropical central Pacific Ocean were observed in the El Niño years (Fig. 2c). In the La Niña years, positive signals in AOD over the eastern and western Indian Ocean and the tropical central Pacific Ocean, and negative signals in AOD over Australia and the tropical eastern Pacific Ocean were observed (Fig. 2d). The signs of AOD anomalies were opposite between the El Niño and La Niña years, which is associated with precipitation anomalies.

These signals were statistically significant, which indicates that AOD fluctuates in a small number of extreme ENSO events (e.g., Nakajima et al. 1999) and many moderate ENSO events. Furthermore, AOD signals corresponded to the precipitation signals, particularly over the tropics. The correlation coefficients between the three-month mean AOD and precipitation for 20002012 over the Maritime Continent $\left(105^{\circ} \mathrm{E}-140^{\circ} \mathrm{E}, 10^{\circ} \mathrm{S}-5^{\circ} \mathrm{N}\right)$ 
Aerosol Optical Depth

(a)SON EINino-climatology composite(95\%)

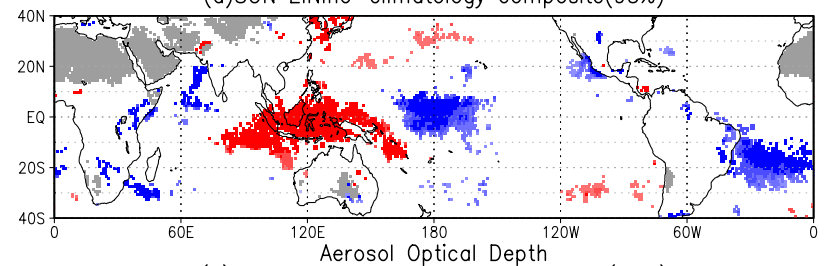

(b)SON LaNina-climatology composite(95\%)

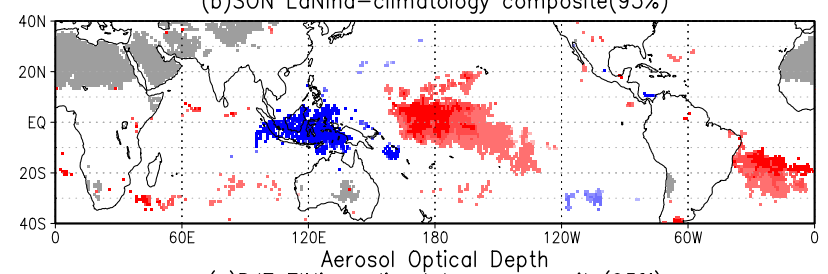

(c)DJF EINino-climatology composite(95\%)

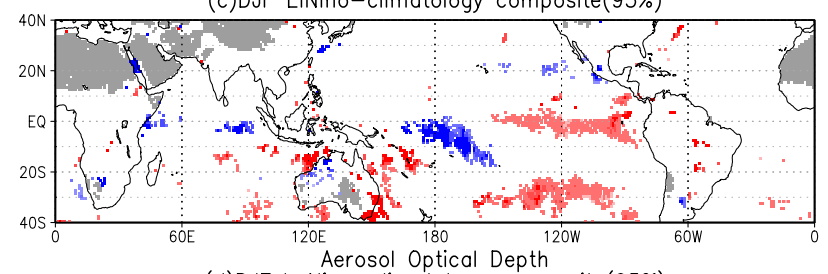

(d)DJF LaNina-climatology composite(95\%)

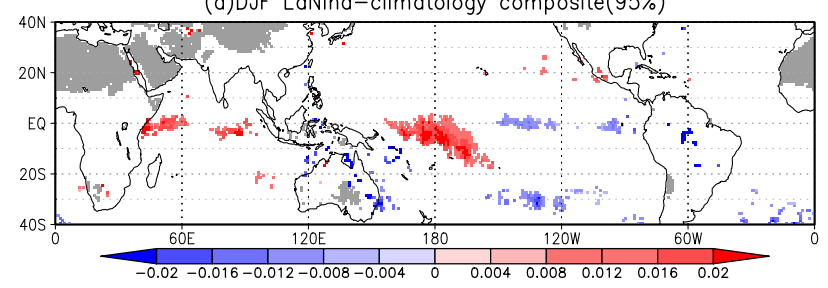

Fig. 2. Same as Fig. 1 but for aerosol optical depth. Gray portions indicate missing values.

were -0.92 in SON and -0.54 in DJF.

As described in Section 2.3, the slightly less number of AOD samples in DJF over the ocean may be associated with unclear signals in DJF. We cannot evaluate whether the unclear signals were actually weak signals or a sampling issue.

AOD anomalies over the Maritime Continent in SON were larger in the El Niño years than in the La Niña years, whereas precipitation anomalies over the Maritime Continent in SON in the El Niño years were primarily equivalent to those in the La Niña years. This result shows that the absolute AOD anomaly values were larger under drier condition. A detailed discussion is provided in Section 4.

\section{b. Possible source of AOD over the Maritime Continent}

One of the main sources of aerosols over the Maritime Continent is biomass burning (van der Werf et al. 2008). We investigated the interannual variation in the sources of aerosols over the Maritime Continent by using the Global Fire Emission Database version 3 (van der Werf et al. 2010). The correlation coefficient between AOD and organic carbon was 0.94 (see Supplement 1), which indicated that the interannual variation in the sources of aerosols over the Maritime Continent corresponds to that in AOD, which is likely associated with surface conditions partly through the precipitation variations.

\subsection{Cloud Effective Radius}

CER can further change with a change in aerosol burden. In SON, statistically significant positive CER signals were observed over the tropical central Pacific Ocean and negative signals were observed over the Maritime Continent in the El Niño years (Fig. $3 a)$. In the La Niña years, positive and negative CER signals were essentially opposite (Fig. 3b).
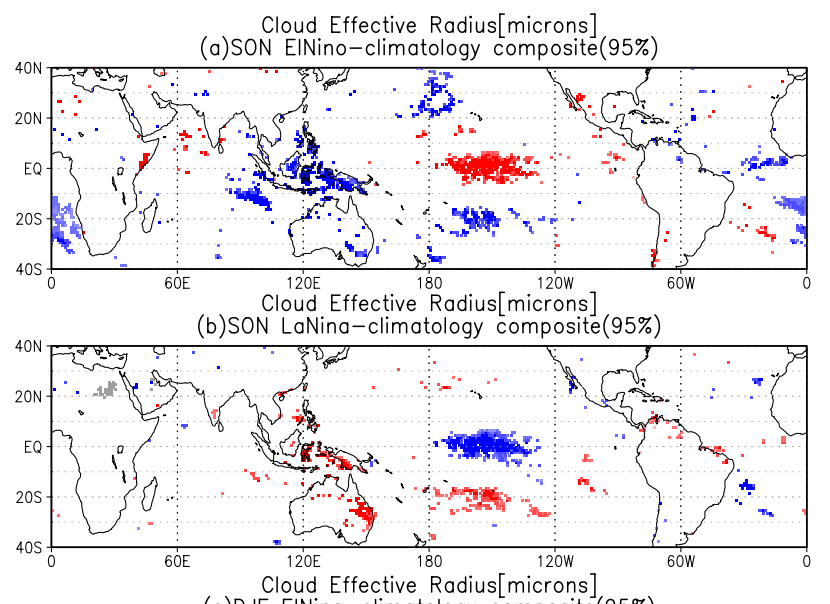

(c)DJF EINino-climatology composite(95\%)

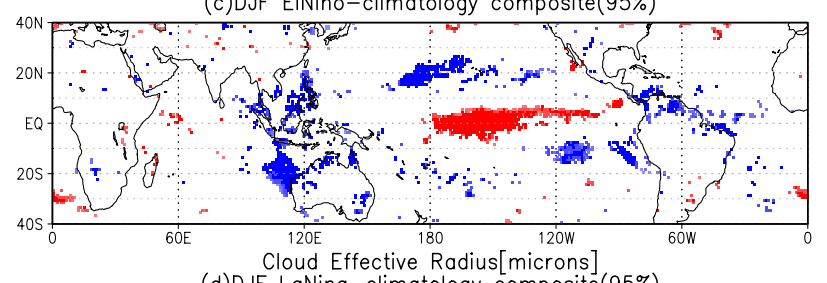

(d)DJF LaNina-climatology composite(95\%)

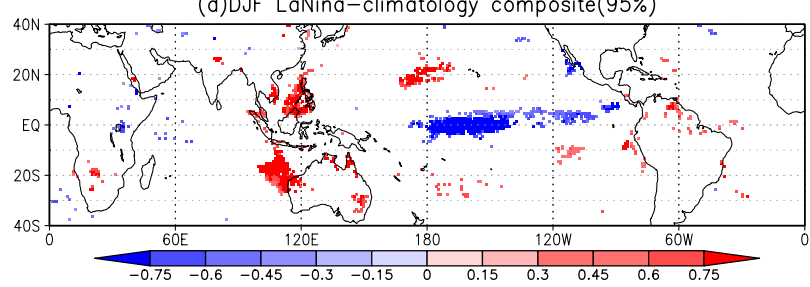

Fig. 3 Same as Fig. 1 but for cloud effective radius (unit is $\mu \mathrm{m}$ ). Gray portions indicate missing values.

In DJF, statistically significant positive CER signals were observed over the tropical central Pacific Ocean, and negative signals were observed over the Maritime Continent, mid-latitude North Pacific Ocean, and off the coast of Peru in the El Niño years (Fig. 3c). In the La Niña years (Fig. 3d), the distribution was opposite to the El Niño years.

The correspondence of statistically significant signals between AOD and CER was observed on interannual time-scales, which implies a physical linkage, i.e., aerosol-cloud-precipitation interaction, on an interannual time-scale. This result is consistent with Suzuki et al. (2010) that indicated aerosol amount significantly modifies the correlation pattern between CER and cloud optical thickness mainly through changing cloud particle number concentrations.

\section{Discussions}

\subsection{Asymmetry of interannual variation in AOD over the Mari- time Continent}

The previous section showed the asymmetry of interannual variations in AOD between El Niño and La Niña in SON. To understand the asymmetry of interannual variations in greater detail, a scatterplot between the three-month mean AOD and the precipitation for 2000-2012 over the Maritime Continent is shown in Fig. 4. Figure 4a shows that the magnitude of AOD anomalies in the El Niño years was larger than in the La Niña years, whereas precipitation anomalies in the El Niño years were primarily equivalent to those in the La Niña years.

To investigate this asymmetry of interannual variation in AOD quantitatively, we conducted regression analysis and compared two cases. We calculated a regression line by the least-squares 

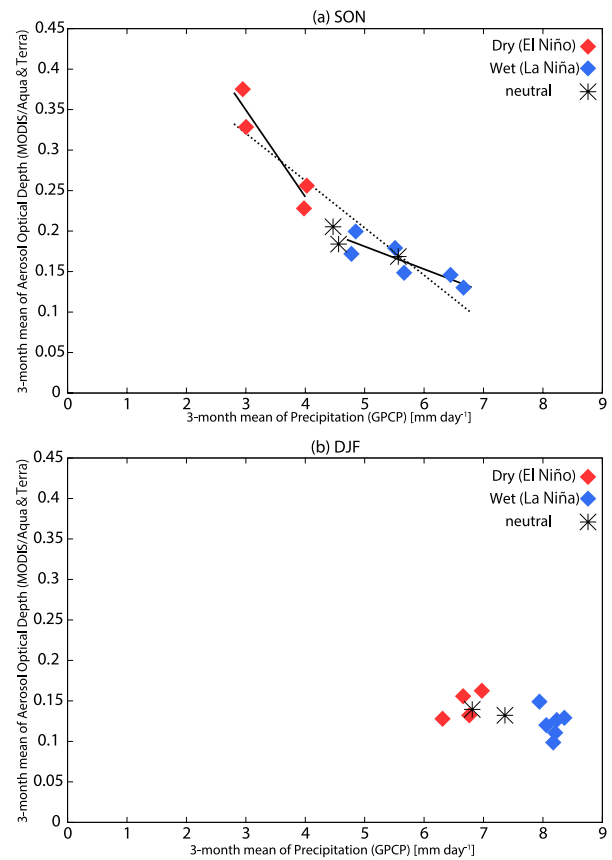

Fig. 4 Scatterplot between three-month mean precipitation (unit is $\mathrm{mm}$ day $^{-1}$ ) and AOD (from Terra and Aqua) over the Maritime Continent $\left(105^{\circ} \mathrm{E}-140^{\circ} \mathrm{E}, 10^{\circ} \mathrm{S}-5^{\circ} \mathrm{N}\right)$ from 2000 to 2012 in (a) SON and (b) DJF. Red, blue rhombus, and asterisk symbols are values for dry (El Niño), wet (La Niña), and neutral years respectively. Lines in (a) are least-squares regression fits to data points using values from the El Niño and La Niña years together (dotted line) and separately (solid lines).

method using the values from both El Niño and La Niña years (dotted line in Fig. 4). Furthermore, we calculated two regression lines using the values from El Niño and La Niña years, separately (solid lines in Fig. 4). The latter case showed that the slope of the regression line for the El Niño years was steeper than that for La Niña years, which indicates that the AOD response to precipitation was larger in drier conditions than wetter conditions. Additionally, we calculated Akaike's information criterion (AIC; Akaike 1974) for the two cases. AIC is a criterion that is used to determine which model (regression line) is most suitable. The model with a smaller value was judged to be suitable (Kitamura et al. 2004). The AIC of the two cases were -35.3 and -43.8 , respectively. This shows that the case fitted by two regression lines was more suitable for modeling the relationship between precipitation and AOD. Therefore, the AOD response was significantly more sensitive to precipitation in drier conditions than wetter conditions.

Here we discuss the physical mechanism, which explains the asymmetrical response of AOD to precipitation. We focus on the strength of aerosol-cloud interaction. Figure 5 showed that changes of AOD and CER for wetter years (blue symbols) are smaller than those for drier years (red symbols), because values in AOD and CER for wetter years are much closer to neutral years than drier years. In addition, the similar interannual variation in AOD-CER-precipitation was observed over the tropical central Pacific Ocean (Supplement 2). When precipitation decreases, large amounts of aerosols persist in the atmosphere, which, in turn, suppresses formation and development of clouds and precipitation. The decrease in precipitation is associated with an increase in aerosol emissions and their precursor gases through decreases in soil wetness, and increases in surface air temperature, leaf temperature, and biomass burning. These changes can further increase AOD. The increased AOD can in turn suppress the formation and development of clouds and precipitation (e.g., Suzuki et al. 2010). This feedback is likely stronger under drier conditions. Each component of this presumable feedback on the interannual time-scale was statistically confirmed in this study.

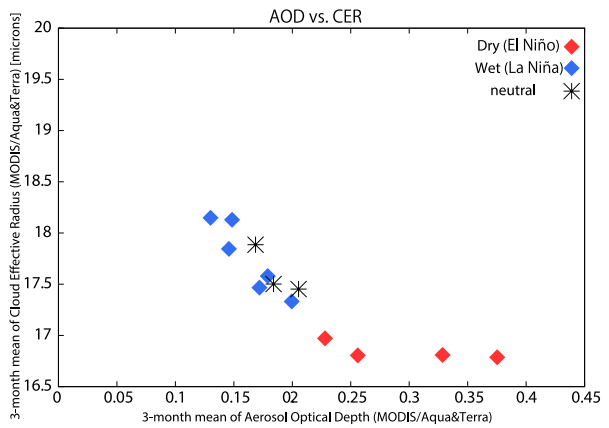

Fig. 5 Scatterplot between three-month mean AOD (from Terra and Aqua) and CER (unit is $\mu \mathrm{m}$ ) over the Maritime Continent $\left(105^{\circ} \mathrm{E}-140^{\circ} \mathrm{E}\right.$, $10^{\circ} \mathrm{S}-5^{\circ} \mathrm{N}$ ) from 2000 to 2012 in SON. Red, blue rhombus, and asterisk symbols are values for dry (El Niño), wet (La Niña), and neutral years respectively.

\subsection{Seasonal difference of interannual variation in AOD over the Maritime Continent}

Here we discuss the seasonal amplitude difference in interannual variation in AOD between SON and DJF over the Maritime Continent. The AOD value in SON (Fig. 4a) was greater than that of DJF (Fig. 4b), which is consistent with Wu et al. (2013). The standard deviation of interannual variation in AOD in SON was 0.072 , whereas that in DJF was 0.018 . The variation range in AOD was larger in SON than in DJF. In terms of seasonal difference in precipitation, Fig. 6 shows the climatology of precipitation in SON and DJF around the Maritime Continent. SON is a relatively dry season, and DJF is the major rainy season over the southern Maritime Continent, which implies that the magnitude of interannual variation in AOD is larger in the drier season. This is consistent with the mechanism explained in Section 4.1, i.e., statistically significant aerosol-cloud-precipitation relationship was likely stronger under drier conditions.

\section{Conclusion}

To investigate aerosol-cloud-precipitation interaction statistically on an interannual time-scale, composite analysis for AOD, CER, and precipitation over the tropics based on ENSO phases was conducted using satellite-based aerosol, cloud, and precipitation data and atmospheric reanalysis for approximately 13 years (2000-2012).

The results show that, over the Maritime Continent, AOD increased in the El Niño years and decreased in the La Niña years, particularly in SON, which corresponded to a decrease in precipitation and increase in precipitation, respectively. Furthermore, CER decreased in the El Niño years and increased in the La Niña years associated with changes in AOD and precipitation, which implies that aerosol-cloud interactions occur on an interannual time-scale.

An asymmetrical response of AOD variation to precipitation anomalies between El Niño and La Niña years in SON was observed over the Maritime Continent, which was statistically robust. Note that this response was stronger under drier conditions than wetter conditions, which was observed over the Maritime Continent and the tropical central Pacific Ocean.

When precipitation decreases, increased aerosols can suppress the formation and development of cloud and precipitation and can dry the surface, which leads to increase AOD through decreases in wet deposition and increases in emissions of aerosols. Therefore, we conclude that this feedback among aerosols, cloud, and precipitation tends to be stronger under drier conditions, which can explain the asymmetrical co-variation among them over the Maritime Continent and the tropical central Pacific Ocean on an interannual time-scale. Furthermore, this can explain the seasonal difference in interannual variation in AOD between SON and DJF over the Maritime Continent because SON is a dry season and 

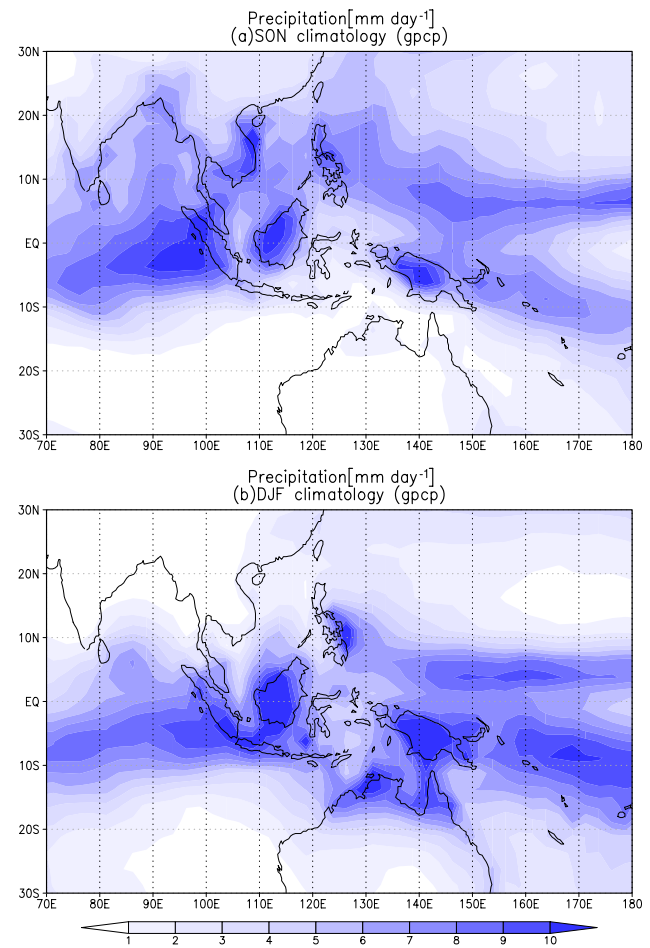

Fig. 6 Climatology of three-month mean precipitation in (a) SON and (b) DJF around the Maritime Continent (unit is $\mathrm{mm} \mathrm{day}^{-1}$ ).

DJF is a rainy season in this region. Finally, our estimation can be useful to evaluate simulated interannual variations in AOD, CER, and precipitation using global and regional climate models.

\section{Acknowledgements}

We are grateful to Dr. Jun Matsumoto for his helpful comments, and Dr. Hiroshi Matsuyama for his statistically constructive comments. We thank three anonymous reviewers for their valuable comments. This study was partly supported by the "Green Network of Excellence (GRENE)" program of the MEXT, Japan, the 7th JAXA PMM Project No. 306, and the Global Environment Research Fund of the Ministry of the Environment.

\section{Supplement}

Supplement 1 shows interannual variations of AOD and organic carbon in SON over the Maritime Continent. Supplement 2 shows the scatterplots between precipitation and AOD, and AOD and CER in SON over the tropical central Pacific Ocean.

\section{References}

Adler, R. F., G. J. Huffman, A. Chang, R. Ferraro, P. Xie, J. Janowiak, B. Rudolf, U. Schneider, S. Curtis, D. Bolvin, A. Gruber, J. Susskind, P. Arkin, and E. Nelkin, 2003: The Version 2 Global Precipitation Climatology Project (GPCP) Monthly Precipitation Analysis (1979-Present). J. Hydrometeorology, 4, 1147-1167.

Akaike, H., 1974: A new look at the statistical model identification. IEEE Trans. Autom. Control, 19, 716-723.

Andreae, M. O., D. Rosenfeld, P. Artaxo, A. A. Costa, G. P. Frank, K. M. Longo, and M. A. F. Silva-Dias, 2004: Smoking rain clouds over the Amazon. Science, 303, 1337-1342.

Climate Prediction Center, 2013: Climate Prediction Center - Monitoring \& Data: ENSO Impacts on the U.S. - Previous Events. (online), available from http://www.cpc.ncep.noaa.gov/products/ analysis_monitoring/ensostuff/ensoyears.shtml, (accessed 2013/
$12 / 13)$.

Jeoung, H., C. E. Chung, T. V. Noije, and T. Takemura, 2014: Relationship between fine-mode AOD and precipitation on seasonal and interannual time scales. Tellus $B, \mathbf{6 6}, 23037$.

Kitamura, A., T. Izumi, and H. Matsuyama, 2004: Relationship among surface temperature estimated by surface energy budget, ground air temperature and brightness temperature of Landsat-5 TM. J. Geogr., 113, 495-511 (in Japanese with English abstract).

Lohmann, U., and G. Lesins, 2002: Stronger constraints on the anthropogenic indirect aerosol effect. Science, 298, 1012-1015.

Nakajima, T. Y., and T. Nakajima, 1995: Wide-area determination of cloud microphysical properties from NOAA AVHRR measurements for FIRE and ASTEX regions. J. Atmos. Sci., 52, 40434059.

Nakajima, T., A. Higurashi, N. Takeuchi, and J. R. Herman, 1999: Satellite and ground-based study of optical properties of 1997 Indonesian forest fire aerosols. Geophys. Res. Lett., 26, 2421-2424.

Onogi, K., J. Tsutsui, H. Koide, M. Sakamoto, S. Kobayashi, H Hatsushika, T. Matsumoto, N. Yamazaki, H. Kamahori, K. Takahashi, S. Kadokura, K. Wada, K. Kato, R. Oyama, T. Ose, N. Mannoji, and R. Taira, 2007: The JRA-25 reanalysis. J. Meteor. Soc. Japan, 85, 369-432.

Penner, J. E., 2001: Aerosols, their direct and indirect effects. Climate Change 2001: The Scientific Basis. 348 pp.

Salomonson, V. V., W. L. Barnes, P. W. Maymon, H. E. Montgomery, and H. Ostrow, 1989: MODIS: Advanced facility instrument for studies of the Earth as a system. IEEE Trans. Geosci. Remote Sens., 27, 145-153.

Shi, Y., J. Zhang, J. S. Reid, B. Holben, E. J. Hyer, and C. Curtis, 2011: An analysis of the collection 5 MODIS over-ocean aerosol optical depth product for its implication in aerosol assimilation. Atmos. Chem. Phys., 11, 557-565.

Smith, T. M., R.W. Reynolds, T. C. Peterson, and J. Lawrimore, 2008: Improvements to NOAA's Historical Merged Land-Ocean Surface Temperature Analysis (1880-2006). J. Clim., 21, 22832296.

Solomon, S., D. Qin, M. Manning, M. Marquis, K. Averyt, M. M. B. Tignor, H. L. Miller Jr., and Z. Chen, Eds., 2007: Climate Change 2007: The Physical Science Basis, Cambridge University Press, 996 pp.

Stocker, T. F., D. Qin, G.-K. Plattner, M. Tignor, S. K. Allen, J. Boschung, A. Nauels, Y. Xia, V. Bex, and P. M. Midgley Eds., 2013: Climate Change 2013: The Physical Science Basis, Cambridge University Press, $1535 \mathrm{pp}$.

Suzuki, K., T. Nakajima, A. Numaguti, T. Takemura, K. Kawamoto, and A. Higurashi, 2004: A Study of the aerosol effect on a cloud field with simultaneous use of GCM modeling and satellite observation. J. Atmos. Sci., 61, 179-194.

Suzuki, K., T. Nakajima, T. Y. Nakajima, and A. Khain, 2006: Correlation pattern between effective radius and optical thickness of water clouds simulated by a spectral bin microphysics cloud model. SOLA, 2, 116-119.

Suzuki, K., T. Nakajima, T. Y. Nakajima, and A. P. Khain, 2010: A Study of microphysical mechanisms for correlation patterns between droplet radius and optical thickness of warm clouds with a spectral bin microphysics cloud model. J. Atmos. Sci., 67, $1126-1141$

Tosca, M. G., J. T. Randerson, C. S. Zender, M. G. Flanner, and P. J. Rasch, 2010: Do biomass burning aerosols intensify drought in equatorial Asia during El Niño? Atmos. Chem. Phys., 10, 35153528.

van der Werf, G. R., J. Dempewolf, S. N. Trigg, J. T. Randerson, P. S. Kasibhatla, L. Giglio, D. Murdiyarso, W. Peters, D. C. Morton, G. J. Collatz, A. J. Dolman, and R. S. DeFries, 2008: Climate regulation of fire emissions and deforestation in equatorial Asia. Proc. Natl. Acad. Sci. U.S.A., 105, 20350-20355.

van der Werf, G. R., J. T. Randerson, L. Giglio, G. J. Collatz, M. Mu, P. S. Kasibhatla, D. C. Morton, R. S. DeFries, Y. Jin, and T. T. van Leeuwen, 2010: Global fire emissions and the contribution of deforestation, savanna, forest, agricultural, and peat fires (1997-2009). Atmos. Chem. Phys., 10, 11707-11735.

Wu, R., Z. Wen, and Z. He, 2013: ENSO contribution to aerosol variations over the Maritime Continent and the western North Pacific during 2000-2010. J. Clim., 26, 6541-6560.

Manuscript received 14 August 2014, accepted 27 October 2014 SOLA: https://www.jstage.jst.go.jp/browse/sola/ 